\title{
$\begin{array}{lllllllllllllllll}\mathbf{R} & \mathbf{O} & \mathbf{Z} & \mathbf{P} & \mathbf{R} & \mathbf{A} & \mathbf{W} & \mathbf{Y} & \text { I } & \text { A } & \mathbf{R} & \mathbf{T} & \mathbf{Y} & \mathbf{K} & \mathbf{U} & \mathbf{L} & \mathbf{Y}\end{array}$
}

Prawo Kanoniczne

60 (2017) nr 1

DOI:10.21697/pk.2017.60.1.01

O. TOMASZ GAŁKOWSKI CP

Wydział Prawa Kanonicznego

Uniwersytetu Kardynała Stefana Wyszyńskiego w Warszawie

\section{UŻYTECZNOŚĆ OKREŚLANIA METODY W KANONISTYCE}

Treść: Wstęp. - 1. Przedmiot badawczy kanonistyki. - 2. Cel badawczy kanonistyki. - 3. Metoda badawcza kanonistyki. - 4. Wnioski.

\section{Wstęp}

Na wstępie niniejszego opracowania należy wyjaśnić: (a) temat zawarty w jego tytule, (b) kontekst podjętych dywagacji. Przeprowadzane rozważania, co należy podkreślić już na samym początku, nie dotyczą metody w kanonistyce, lecz użyteczności jej określania. Temat metody zostanie podjęty jedynie w jego elementarnym zarysie, gdyż bez niego trudno mówić o użyteczności określania metody. Jej bowiem ujęcie w znacznej mierze wpływa na jej użyteczność.

Zacznijmy od drugiego wyznacznika. Dotyczy on pewnej nieporadności metodologicznej związanej z przygotowaniem pracy magisterskiej czy doktorskiej. Wymogiem stawianym takim opracowaniom jest przedstawienie metody, zwanej naukową, w oparciu o którą autor opracowania doszedł do prezentowanych wniosków. Prezentacja metod wskazuje na dość dużą ich swobodę i dowolność, które jednocześnie przybierają wręcz oszałamiające rozwiązania. Te z kolei prowadzą do pytań o ich nowatorstwo (jeśli tak, to chwała badaczom), a tym samym o poprawność lub, co częściej się zdarza, o podstawy metodologii. To drugie pytanie jest wynikiem wrażenia podbudowanego doświadczeniem, iż dobór metody jest końcowym elementem opracowania przygotowanego do przedstawienia czy do 
druku. Metoda powinna zostać zakreślona. Trzeba zatem ją wymienić. I jest to powodem nieuniknionych kłopotów, gdyż często trudno autorowi opracowania wskazać na wnioski, które są efektem zastosowania wymienionych metod. Ponadto samo zasugerowanie metod, czasami słusznie obecnych, nie oznacza ich faktycznego zastosowania, gdyż autorzy opracowań nie potrafią określić, nawet nie szczegółowo, poszczególnych elementów charakterystycznych dla metody, nie mówiąc już o zawiłościach dotyczących właściwego rozumienia tychże elementów. Z tego też powodu warto zapytać się o uży teczność określania metody w kanonistyce, skoro w „naukowych” opracowaniach nie znajduje ona swojego odniesienia.

Użyteczność określenia metody w kanonistyce wiąże się z kwestiami powszechnie dyskutowanymi w obrębie nauk, w których uczestniczy także i kanonistyka oraz w ramach samej kanonistyki, której natura naukowa pozostaje również dyskusyjna. Natura nauki zależy bowiem od odpowiedzi na trzy pytania ${ }^{1}$. Pierwsze pytanie brzmi: co nauka bada? czyli jaki jest przedmiot badawczy. Już na tym poziomie dostrzega się rozbieżności, które będą wpływały na metodę badawczą jak i określenie kanonistyki jako nauki prawnej czy teologicznej. Drugie pytanie dotyczy celu. Chodzi o określenie celu przedmiotowego w odróżnieniu od celów podmiotowych naukowców. Trzecie pytanie dotyczy metody. Odpowiedzi na trzy powyższe pytania tłumaczą naturę nauki.

Skrótowa jedynie odpowiedź na powyższe pytania - w miarę wyczerpująca odpowiedź wymagałaby samodzielnych opracowań może okazać się przydatna do stwierdzenia użyteczności lub nie określania metod w kanonistyce i w pracy „naukowej”.

\section{Przedmiot badawczy kanonistyki}

Kanonistyka czyli nauka prawa kanonicznego posiada jak każda nauka prawa, bo tak w ogólnym mniemaniu oraz w niektórych naukowych ujęciach czy klasyfikacjach istnieje, za swój przedmiot badawczy prawo. Bardzo ogólnie określony przedmiot badawczy

${ }^{1}$ Z. HAJduk, Ogólna metodologia nauk, Lublin, Wydawnictwo KUL, 2012, s. 146. 
nauk prawnych odróżnia go od jakiegokolwiek innego, który nie wchodzi w zakres pojęcia prawa. Już jednak desygnaty pojęcia nie wskazują na jednoznaczność przedmiotu badawczego. Prawo jest bowiem określane jako fakt językowy, jako przeżycie psychiczne, jako fakt społeczny, jako wartość. Wszystkie te przykładowo wskazane desygnaty mieszczą się w zakresie jednego pojęcia pomimo tego, że wskazują na czasami wykluczające się rzeczywistości. Odzwierciedla to sformułowanie wskazujące, że prawo istnieje w działaniu, ale nie w książkach (law in action, law in books). W zależności od przyjętych sposobów ujmowania prawa oraz celów badawczych będą istniały również odpowiednie metody umożliwiające jego poznanie.

Przedmiot badawczy określony mianem prawa nie oznacza zatem, że punkt wyjścia jest ten sam dla wszystkich badaczy. Wszyscy mogą zajmować się prawem, ale pozostaje pytanie dotyczące tego, czym faktycznie się zajmują: pojęciem czy jedną z rzeczywistości zakreślonej pojęciem. Efektem takiego podejścia stało się aspektowe podejście do badanego przedmiotu, które często rościło sobie pretensje do całościowego wyrażenia rzeczywistości obejmowanej pojęciem. Redukcja przedmiotu badawczego w znacznej mierze przyczyniła się do uzależnienia od niego metod badawczych.

Z podobną sytuacją mamy do czynienia w przypadku prawa kanonicznego. W zakresie tego pojęcia mieści się prawo Boże, zgodnie $\mathrm{z}$ akceptowanym Suareziańskim określeniem, pozytywne i naturalne w takiej mierze, w jakiej ma związek z prawem kanonicznym oraz prawo czysto kościelne, stanowione. Do wszystkich rodzajów stosowane jest to samo pojęcie prawa. Czy jednak jako desygnat tego samego pojęcia oznacza tę samą rzeczywistość? Rozbieżności są znaczne, zwłaszcza te, które odnoszą się do jednoznacznego określenia tego, czym jest prawo Boże, czy można w odniesieniu do niego stosować w ogóle pojęcie prawa, jakie warunki i czy musi je spełniać, by można je było nazwać prawem? ${ }^{2}$

\footnotetext{
2 T. GAŁкоwsкi, O adekwatności lub nie pojęcia prawa w prawie Bożym, Seminare 31(2012), s. 11-24.
} 
Zestawienie problemów związanych z określeniem przedmiotu nauk prawnych i kanonistyki pozwala wskazać na elementy wspólne prawa i prawa kanonicznego. Jest nim zobowiązujący (koniecznościowy) charakter relacji międzyosobowych ${ }^{3}$. W przypadku prawa kanonicznego ich moc wiążąca nie posiada swego źródła jedynie w rzeczywistości społecznej, lecz w wymiarze wiary, która posiada dla ochrzczonych charakter zobowiązujący. Prawo kanoniczne jest prawnym wymiarem wiary, a tym samym prawnym wymiarem Kościoła. Stosunki prawne w Kościele nie powstają, zmieniają się czy zanikają jedynie ze względu na naturę społeczną człowieka, lecz z powodu tworzenia chrześcijańskiej wspólnoty powstałej jako komunii, wspólnoty bosko-ludzkiej, w której i poprzez którą realizuje się zbawienie. Specyfika stosunków międzyosobowych wynikających z przyjętego sakramentu chrztu i kościelnego ich umiejscowienia wpływa na specyfikę prawa kościelnego ${ }^{4}$. Różni się ono od prawa społeczności świeckiej pod względem formalnym (poziom jurydyczności/ normatywności) i materialnym (treściowym). Tym samym poznanie prawa kanonicznego jest nieodzowne od wcześniejszego poznania Kościoła. Nie można traktować o prawie kościelnym pomijając to, co wyznaczone jest jego specyfiką i jest zawarte w sformułowaniu «kościelne». Jest to prawo charakterystyczne dla specyficznej formy życia wspólnotowego w oparciu o wertykalne wezwanie i horyzontalne zobowiązanie. Chrześcijańska wiara i jej praktyka mają koniecznościowy wymiar społeczny.

Przedmiotem poznania kanonistyki jest zatem na pierwszym miejscu Kościół. Jest on również przedmiotem poznania wielu innych nauk zarówno teologicznych jak i nieteologicznych. Tym co łączy przedmiot poznania prawa kanonicznego z przedmiotem poznania innych nauk teologicznych jest Kościól, który dla nich wszystkich jest wspólnotą wiary. Kościół jako wspólnota bosko-ludzka nie jest

\footnotetext{
${ }^{3}$ A. Rouco Varela, E. Corecco, Sacramento e diritto: antinomia nella Chiesa?, Milano: Jaca Book, 1971, s. 64.

${ }^{4}$ R. SobAŃski, Nauki podstawowe prawa kanonicznego. T. 2. Teologia prawa kościelnego, Warszawa, UKSW, 2001, s. 51-56.
} 
tym samym, co jakakolwiek inna wspólnota oparta na więzach naturalnych. Prawo tej wspólnoty nie jest prawem społeczności, którą różni od każdej innej tylko jej religijny charakter, lecz wspólnoty jako komunii bosko-ludzkiej. Prawo takiej wspólnoty nie bazuje na jej filozoficznych czy socjologicznych założeniach. Nie może być zatem stawiane na równi z prawem społeczności naturalnej i badane za pomocą metod jemu właściwych.

Określenie przedmiotu kanonistyki jako prawnego wymiaru Kościoła oznacza, że kanonistyka zajmuje się Kościołem w aspekcie prawnym. Kościół ma swoją wewnętrzną naturę, której nieodłącznym elementem zakorzenionym w Słowie i sakramencie jest prawo. Prawo nie istnieje jako coś dodanego do Kościoła. Tworzy z nim nierozłączną jedność. Chcąc poznać prawo Kościoła, należy zatem poznać i Kościół. Mówiąc inaczej, poznając Kościół można poznawać także i jego wymiar prawny tworząc eklezjologię prawną. Kanonistyka zajmując się Kościołem czyni to zatem w aspekcie prawnym i to różni kanonistę od eklezjologa. Kanonistyka nie zajmuje się zatem aspektami prawnymi Kościoła, tak jakby mogły być do niego dodane a on sam mógłby istnieć bez nich, a o których może również dywagować teolog. Kanonistyka nie jest zainteresowana również samym uzasadnianiem istnienia prawa w Kościele, gdyż może i powinno stanowić to przedmiot eklezjologii, lecz tym, w jaki sposób prawo Kościoła, jako jeden z elementów jego struktury, uczestniczy w misji spełnianej przez Kościół, w jaki sposób także i poprzez prawo Kościół realizuje zbawienie.

Co z takiego określenia przedmiotu kanonistyki wynika dla rozważań o metodzie? Po pierwsze: metoda, którą posługuje się kanonistyka będzie wskazywała na jej specyfikę, powodując, że nie można sprowadzić i kształtować metody kanonistyki odwołując się jedynie do metod, które występują w naukach prawnych i stawiając ją na równi z nimi. Decyduje o tym przedmiot kanonistyki, którego istota zawarta jest w Objawieniu i z niego dedukowana. W konsekwencji poznanie prawa kanonicznego dokonuje się w świetle danych Objawienia (fides quae) przyjmowanych poprzez wiarę (fides qua) 
pod kierownictwem Nauczycielskiego Urzędu Kościoła ${ }^{5}$. Ten sposób poznania wyznacza zatem reguły, zasady, kategorie determinowane przez wiarę biorąc pod uwagę wymogi chrześcijańskiej sprawiedliwości odczytywane w kontekście historycznym wspólnoty, w której i poprzez którą spełnia się jej posłannictwo ${ }^{6}$.

Drugi wniosek dotyczy sposobu traktowania źródeł prawa. Ich określenie w obszarze wszelkich dostępnych danych Objawienia i usystematyzowanie wyznacza charakterystyczna dla nich kategoria prawna. Nie są to również źródła prawa poddane kościelnemu oglądowi i interpretacji w świetle danych Objawienia. Ich szczególny charakter prawny wyznaczony jest bowiem przez ich pochodzenie i treściową zawartość. Tym samym źródła prawa kanonicznego wykazują swoją specyfikę ze względu na to, że w swej najgłębszej istocie są źródłami teologicznymi. Specyfika zatem przedmiotu prawa kanonicznego decyduje również o punkcie wyjścia stanowienia prawa pozytywnego, jego interpretacji i metod badawczych. Nie dyskwalifikuje to jednak możliwości aplikacji metod występujących w naukach prawnych, ale ustawia pewne nieprzekraczalne granice. Prawo kanoniczne może być obiektem badań różnych nauk i metod, z różnych punktów widzenia, których jednak nie można stawiać na tym samym poziomie poznawczym i traktować dowolnie według własnych upodobań i wyborów. W kanonistyce mamy bowiem do czynienia nie z prawem, lecz z prawem Kościoła 7 . Dążąc do poznania prawa kanonicznego, specyficznej treści stosunków prawnych nie można bez obaw błędu metodologicznego i zafałszowania odwoływać się jedynie do nauk prawnych, lecz należy poszukiwać ich tam, gdzie prawo bierze swój poznawczy początek, czyli w wierze Kościoła (unde Ecclesia, ibi ius).

\footnotetext{
${ }^{5}$ Sobór WАтүкаŃski II, Dekret o formacji kapłańskiej, n. 16.

${ }^{6}$ A. Cattaneo, Fondamenti ecclesiologici del diritto canonico, con la collaborazione di Costantino-M. Fabris, Venezia, Marcianum Press, 2011, s. 119.

${ }^{7}$ W. Aymans, Osservazioni critiche sul metodo della canonistica, w: Scienza giuridica e diritto canonico, a cura di R. Bertolino, Torino, Giappichelli Editore, 1991, s. 101-104.
} 
Kolejny wniosek dotyczy normy kanonicznej jako specyficznego przedmiotu poznania celem właściwej aplikacji. Stwierdzenie, że prawo kanoniczne należy do struktury Kościoła nie oznacza, że każda norma kanoniczna należy do tejże struktury. Oznacza jedynie, że Kościół istnieje również w wymiarze prawnym. Można jednak stwierdzić, że norma kanoniczna ma swoje koniecznościowe odniesienie do tejże struktury i ją wyraża, wyjaśnia i uzmysławia. Poszukiwanie adekwatnych metod jej poznania, prawidłowego odczytania i aplikacji nie może pomijać faktu, iż jest to norma kanoniczna istniejąca w i dla wspólnoty, która jawi się jako komunia, w której prawo tę komunię wyraża i pomaga ją zachować. Komunia kościelna jest elementem scalającym wszystkie wymiary Kościoła i jednocześnie o nich decydującym. W świetle tej jedności komunijnej należy zatem odczytywać normy, które jej służą i ją urzeczywistniają.

Wskazując na specyfikę przedmiotu kanonistyki można uniknąć sytuacji, w którą wpadła nauka prawna, a mianowicie redukcji przedmiotu w jego różnych wymiarach skutkującym traktowaniem pars pro toto. Przed takim podejściem broni łączność prawa z wiarą i zakorzenienie w strukturze Kościoła. Na takim podejściu korzysta również sam Kościół. Unika on redukcji do jakiegoś spośród swoich obrazów, za pomocą których jest przedstawiany i wiążącego się z nim bardziej lub mniej wyraźnie prawa, czemu dają wyraz sposoby badania prawa oparte na konsekutywnym ujęciu tej zależności.

\section{Cel badawczy kanonistyki}

Metoda (od grec. methodos) w pierwotnym znaczeniu oznacza drogę do osiągnięcia czegoś, a następnie w znaczeniu przenośnym odpowiednie postępowanie. Obydwa znaczenia łączy cel, który chce się osiągnąć wybierając odpowiednią drogę czy też odpowiednie postępowanie, które ku czemuś zmierza. Cel wyznacza zatem drogę. By wejść na jakąś drogę lub podjąć odpowiednie postępowanie należy wiedzieć dokąd się zmierza i co chce się osiągnąć. Aby wyznaczyć drogę trzeba

\footnotetext{
${ }^{8}$ T. GaŁkowski, Metoda kanonistyczna we współczesnej dyskusji prawnej, Prawo Kanoniczne 54 (2011), nr 3-4, s. 180-181.
} 
znać cel. Ustalając odpowiedniość należy najpierw wiedzieć, czemu coś ma odpowiadać. Cel decyduje zatem o drodze. Ustalenie metody możliwe jest wtedy, gdy wcześniej będzie określony i znany cel ${ }^{9}$.

Cel nauk prawnych wyznaczony jest przez przedmiot, jakim jest prawo. Pytanie, które jest stawiane brzmi następująco: $\mathrm{w}$ jakim celu poznajemy przedmiot-prawo? Następnie pytamy o to, w jaki sposób można ten cel osiągnąć, czyli jak poznać prawo by zrealizować cel poznawczy? Przy tym należy zaznaczyć, że chodzi tu o cel przedsięwzięcia (dzieła), a nie cel podejmującego działanie. Potrzeby poznania prawa prowokowane przez cel powodowały podejmowanie odpowiednich metod umożliwiających jego osiągnięcie, a tym samym zaspokojenie potrzeb. Cel oznacza nie tylko to wszystko, ku czemu działanie zmierza, rozwija się ale stanowi również motyw, pobudkę działania. Motywacja działania znajduje się zatem w celu. Zamiar jego osiągnięcia będzie wpływał zatem na sposób postępowania.

Przedmiot i cel określają zatem odpowiednie sposoby postępowania. W odniesieniu do prawa J. Stelmach i B. Brożek wskazują na trzy zakresy stosowania metod prawniczych ${ }^{10}$. Pierwszy z nich to zakres praktyczny, w którym odpowiednio stosowane metody w rękach praktyków prawników wykorzystywane są w celu interpretacji i tworzenia prawa. Dogmatycznoprawne zastosowanie metod prawniczych charakterystyczne jest natomiast dla rozważań dotyczących instytucji prawnych (cywiliści, karniści). Ostatni zakres stosowania odpowiednich metod dotyczy teoretycznoprawnych rozważań podejmowanych w teorii i filozofii prawa, w których celem jest odpowiedź na pytania stawiane w tych dziedzinach wiedzy zgodnie ze sposobem ich ujmowania. Autorzy opracowania podkreślają jednak, co wynika $\mathrm{z}$ dokonanych przez nich analiz, że zastosowanie metod prawniczych nie ogranicza się w sposób wyjątkowy do jednego tylko z zakresów. Rzadko się zdarza, by każda ze sfer zastosowania metod prawniczych ograniczała się tylko do jednej dla niej charakterystycznej metody.

\footnotetext{
${ }^{9}$ A. Keller, Wprowadzenie do teorii poznania, Kraków, WAM, 2010, s. 68.

${ }^{10}$ J. Stelmach, B. BrożeK, Metody prawnicze, Kraków, Wolters Kluwer, 2006, s. 32 .
} 
Co więcej, metody te znajdują zastosowanie we wszystkich wymienionych sferach prawniczych zainteresowań. Poza tym wyróżnione przez wspomnianych autorów cztery metody stosowane przez prawników i teoretyków prawa (logika, analiza, argumentacja, hermeneutyka) nie wyczerpują całości możliwych metod. Podział przez nich dokonany nie jest wyczerpujący, ale reprezentatywny dla obecnego stanu wiedzy. Nie jest to również podział rozłączny, gdyż granice pomiędzy poszczególnymi metodami nie są wyraźne. Metody te nie muszą się wzajemnie wykluczać. Związki między nimi sprowadzają się do trzech rodzajów zależności: (1) wszystkie cztery metody mają ze sobą coś wspólnego, gdyż próbują opisać ten sam fenomen, czyli myślenie; (2) są dla siebie komplementarnymi ujęciami rozumowań prawniczych; (3) środki oferowane przez metody dobrane w możliwy sposób składają się na spójną metodę myślenia prawniczego ${ }^{11}$.

Podobny sposób myślenia napotykamy również na gruncie kanonistyki, zwłaszcza w wykonaniu tych kanonistów, którzy przenoszą do kanonistyki schematy i rozwiązania nauk prawnych jednocześnie podkreślając inność i specyfikę prawa kanonicznego. Javier Hervada wyróżnia cztery poziomy poznawcze kanonistyki, które charakteryzują się różnymi stopniami abstrakcji i związanymi z tym metodami poznawczymi w ramach jednej wiedzy kanonistycznej. Należą do nich poziomy: podstawowy (ontologiczny), fenomeniczny (naukowy), kazuistyczny (jak twierdzi Hervada mało interesujący dla rozważań), praktyczny. Odpowiadają im trzy zakresy zastosowania metod do wykorzystania w ramach ogólnej teorii prawa kanonicznego, nauki kanonistycznej na wzór nauk prawnych i jurysprudencji rozumianej jako proces stosowania prawa. Hervada uważa, że są to trzy następujące po sobie poziomy poznawcze w ramach „sztuki kanonistycznej”, posiadające ten sam przedmiot formalny, jakim jest to, co słuszne ${ }^{12}$. Wszystkie poziomy tworzą jedną naukę o charakterze praktycznym sub ratione iusti, tzn. są ukierunkowane, pomimo różnic

\footnotetext{
11 Tamże, s. 269.

${ }^{12}$ J. Hervada, Pensieri di un canonista nell'ora presente, Venezia, Marcianum Press, 2007, s. 68-69.
} 
metodologicznych, ku jednemu celowi, jakim jest określenie tego, co słuszne w społeczności kościelnej. Poziomem praktycznym w pełnym tego słowa znaczeniu jest jedynie poziom ostatni. Pozostałe dwa Hervada określa jako praktyczno-spekulatywne. Pozostają przyporządkowane praktycznemu zastosowaniu prawa kanonicznego, chociaż twierdzenia w nich wypracowane nie mają bezpośredniego zastosowania w praktyce prawniczej. Służą jako podstawa dla poszukiwania tego, co słuszne w momencie aplikacji ogólnie i generalnie sformułowanych na poziomie fenomenicznym za pomocą egzegezy prawnej i systematycznie uporządkowanych norm prawnych (dogmatyka prawa). Ontologiczny poziom poznania prawa kanonicznego dotyczy poznania ostatecznych jego przyczyn i istoty. Poznanie na tym poziomie nie ma jednak charakteru jedynie spekulatywnego. Przedmiotem materialnym procesu poznawczego jest bowiem Kościół ujmowany zawsze sub ratione iustitiae, sub ratione iusti. Ogólna teoria prawa, różniąca się znacznie od pozostałych zakresów badawczych przede wszystkim wyższym stopniem abstrakcji i w konsekwencji własnymi twierdzeniami charakterystycznymi dla sposobu poznania prawa spełnia jednak rolę służebną wobec wiedzy praktycznej. W świetle wyników jej badań można bowiem zweryfikować poprawność oraz wystarczalność lub nie pozytywnych rozwiązań zastosowanych do konkretnych sytuacji ${ }^{13}$.

Inaczej niż cytowani polscy autorzy, hiszpański kanonista o proweniencji świeckiego prawnika twierdzi, że trzy poziomy kanonistycznego poznania pozostają autonomiczne i niezależne, posługując się tylko sobie właściwą metodą. Pozostają jednak w pewnej otwartości na siebie ze względu na jedność celu jakim jest praktyczne zastosowanie. Wiedza kanonistyczna na poziomie praktycznym jest bowiem oświecona i ukierunkowana przez osiągnięcia ogólnej teorii oraz nauki prawa, których wyniki syntetyzuje oraz ukonkretnia w praktycznym zastosowaniu. Nauka prawa ubogaca się natomiast dzięki osiągnięciom poznawczym dokonanym na poziomie podstawowym. Z rozważań Hervady wynika, że autor uznaje konieczność

\footnotetext{
13 Tamże, s. 77-80.
} 
istnienia wielu metod celem poznania prawa kanonicznego. Jednak łatwo zauważyć, że filozofia jak i teologia prawa kanonicznego, charakterystyczne dla poziomu ontologicznego, nie gwarantują ani nie umożliwiają jakiegokolwiek związku z innymi poziomami poznania.

Wyszczególnienie przez Hervadę trzech poziomów poznawczych prawa kanonicznego budzi zastrzeżenia. Podstawowy poziom praktyczny związany ze stosowaniem prawa nie jest przez Hervadę traktowany w naukowych kategoriach poznawczych. Nauka prawa kanonicznego zaczyna się dopiero od drugiego poziomu, na którym mamy do czynienia z działalnością o charakterze egzegetycznym czy systematycznym. Trudno zgodzić się z autorem, że na poziome praktycznym normatywna działalność sądowa i administracyjna nie wymaga naukowego podejścia (np. interpretacja) celem wypracowania odpowiednich norm postępowania. Hervada odmawia jednak tej działalności charakteru naukowego. Tym samym przedmiot odniesień działalności praktycznej przechodzi na wyższy poziom poznawczy. W takiej sytuacji trudno ujmować poziom praktyczny jako najważniejszy w całej działalności poznawczej ${ }^{14}$. Cel procesu poznawczego, choć może być osiągnięty, nie wyznacza jednak uzasadnienia metod naukowego postępowania poznawczego.

Sposób myślenia Hervady można zaakceptować w jednym przypadku. Chodzi tu o sytuację istnienia poznania naukowego istniejącego poza metodą. Przypadek dotyczy zakresu poznawczego samej metody naukowej, a wyraża się w pytaniu: „czy poznanie naukowe to poznanie jedynie metodyczne, czy coś więcej? Inaczej mówiąc, czy metoda naukowa stanowi warunek konieczny i wystarczający (tzw. kryterium) poznania naukowego"15. By odpowiedzieć na te pytania należy określić zasięg (zakres) poznawczy metody obejmujący dwie podstawowe rzeczy: (1) zakres poznawczy co do przedmiotu i celu badań; (2) zakres poznawczy dotyczący kontekstu, w którym metoda

\footnotetext{
${ }^{14}$ W. Aymans, Osservazioni critiche sul metodo della canonistica, s. 114-115.

${ }^{15}$ W. ZARĘBA, Problem metody naukowej $w$ kontekście odkrycia, w: Metodologia: Tradycja i perspektywy, red. M. Walczak, Lublin, KUL, 2010, s. 211.
} 
jest stosowana ${ }^{16}$. Ten problem epistemologicznych dociekań nie stał się jednak tematem rozważań Hervady.

Inspirujące dla problematyki poznawczej prawa kanonicznego, aczkolwiek nieco zapomniane, są rozważania G. Söhngena o trzech podstawowych zakresach prawa kanonicznego. $W$ ramach pierwszego zakresu zwanego przez niego jurydycznym, dostrzega korzyści, które wynikają z korzystania z metod prawnych. Prawo kościelne ma odpowiadać wszelkim kryteriom stawianym prawu. Adekwatność stosowania metod prawniczych podkreśla formalną poprawność prawa. Drugi poziom prawa kanonicznego określany przez Söhngena jako metajurydyczny czy kanoniczny koncentruje się wokół właściwego przedmiotu materialnego kanonistyki, jakim jest nie jakaś społeczność o charakterze religijnym, lecz Kościół wiary. Podkreśla zatem, że przepisy, które określają instytucje prawne i regulują życie wspólnoty kościelnej wyrażają i uobecniają Kościół jako znak i narzędzie zbawienia. Kościół, w którym głoszone jest Słowo i sprawowane są sakramenty jest prawdą wiary i punktem wyjściowym kanonistyki. Trzeci poziom, zwany przez Söhngena metakanonicznym, dotyczy uczestnictwa prawa w misji Kościoła, jego odniesienia do zbawienia, które przenika całe prawo kanoniczne i bez którego nie można, bez popadnięcia w prawny redukcjonizm, rozważać o celu wszelkich rozwiązań normatywnym. Sprawiedliwość prawa kanonicznego ma zatem prowadzić do zbawienia, do łaski. Cel, dla którego Kościół istnieje obecny jest w jego wszystkich elementach strukturalnych, w tym także w jego prawie ${ }^{17}$.

Wyróżnione przez Söhngena trzy zakresy prawa kanonicznego, zupełnie inaczej niż w przypadku Hervady, wskazują na jedność poznawczego konstruktu myślowego wokół celu, jaki jest realizowany przez prawo jako jeden ze środków do realizacji zbawienia. Nie została jednak rozwiązana przez Söhngena kwestia zależności

\footnotetext{
16 Tamże, s. 211.

${ }^{17}$ G. SöHngen, Grunfragen einer Rechtstheologie, München, Pustet Verlag, 1962, s. 64-71.
} 
pomiędzy poznaniem za pomocą metod stosowanych na poziomie jurydycznym a dwoma następnymi.

\section{Metoda badawcza kanonistyki}

Kolejnym elementem określającym naturę nauki jest metoda czyli sposób pozyskiwania wiedzy, dostosowany do określonego przedmiotu i celu. Zagadnieniu metody w nauce poświęcono o wiele więcej czasu i miejsca niż przedmiotowi czy celowi poznania, co poskutkowało: (1) utworzeniem teorii poznania jako nauki zajmującej się poznaniem i (2) przekonaniem, że metoda w sposób zasadniczy, bardziej niż przedmiot i cel, charakteryzuje poznanie naukowe ${ }^{18}$.

Kanonistyce nie jest obca duża część problemów podejmowanych w epistemologii. Dzieli z nimi podstawowe kwestie dyskusyjne jak ta, która została zaznaczona powyżej, a dotycząca możliwości istnienia poznania naukowego niekoniecznie metodycznego. Do tego dochodzą problemy związane z dyskusją wokół uznania jednej wspólnej metody poznawczej i jej adaptacji do różnych nauk czy też przyjęcia wielości szczegółowych metod składających się na metody bardziej ogólne. Kolejna kwestia sporna dotyczy sposobu uprawiania nauki (indukcjonistyczny czy antyindukcjonistyczny), stosowania metody (racjonalizm czy irracjonalizm, empiryzm czy aprioryzm).

Dodatkowe kwestie związane z problematyką metody pojawiają się na gruncie nauk prawnych. Podstawowe pytanie dotyczy istnienia metody prawniczej. Dotychczasowe rozwiązania: (1) takową odrzucają (prawoznawstwo nie jest nauką, nie istnieją zatem metody w prawie); (2) są przykładem metodologicznej heteronomii uznającej, że prawoznawstwo jest nauką o ile korzysta $\mathrm{z}$ metod istniejących w innych dyscyplinach uznawanych za naukowe, (3) wyrażają tezę o autonomii metodologicznej prawoznawstwa, które spełnia kryteria naukowości i w konsekwencji powinno wypracować własną metodologię różną od tej, którą posługują się nauki formalne, przyrodnicze i społeczne

\footnotetext{
18 S. C. NApiórkowski, Jak uprawiać teologię, Wrocław, Wydawnictwo Wrocławskiej Księgarni Archidiecezjalnej, 2002, s. 78.
} 
(humanistyczne) ${ }^{19}$. Metodologia nauk, w tym nauk prawnych nie daje jednoznacznych rozwiązań w kwestiach spornych dotyczących samej metody i jej określenia w ramach nauk prawnych.

Przenosząc kwestie sporne na grunt kanonistyki, można rozważać każdą z nich osobno i poświęcić jej kolejne opracowania. Mogą się one znacząco przyczynić do precyzacji rozwiązań w oparciu o uznawane kryteria naukowości oraz osiągnięte wyniki badań. Kanonistyka (częściej jednak jako prawo kanoniczne w rozumieniu nauki) posiada bowiem swoje miejsce pośród nauk. Kwestią dyskusyjną, także pośród samych kanonistów, pozostaje jej przyporządkowanie do nauk prawnych czy teologicznych. Wiąże się z tym problem określenia albo metody czy metod w niej stosowanych albo jej własnych i jej właściwych. Znaczący wpływ na tę kwestię posiada również dyskutowana w ramach metodologii nauk problematyka ogólna dotycząca zależności pomiędzy nauką, metodą, przedmiotem w określeniu punktu wyjścia decydującym o dalszej specyfice każdej z tych rzeczywistości.

Jedną z trudności w określeniu metody w kanonistyce jest jej jednoznaczne przyjmowanie jako prawnej lub teologicznej, wzajemnie się wykluczających lub istniejących łącznie. Wynika to z faktu, iż, podobnie jak w przypadku nauk prawnych, „trudno mówić o jakiejś metodzie powszechnie i ogólnie obowiązującej w teologii ${ }^{20 "}$. Spowodowane jest to tym, iż teologia „nie stanowi wiedzy metodologicznie i epistemologicznie jednorodnej"21. Wysiłki ujmujące w sposób komplementarny strukturę poznania teologicznego przynoszą rezultaty w postaci jakiejś jednej metody integralnej, której jednak w równym stopniu nie da się stosować we wszystkich działach teologii. Takie podejście na dalszym etapie powoduje kolejne trudności związane ze sprecyzowaniem jej typowej formy: scholastycznej, pozytywnej czy mieszanej ze wszystkimi możliwymi elementami je konstruującymi²2.

\footnotetext{
${ }^{19}$ J. Stelmach, B. BrożeK, Metody prawnicze, s. 11-28.

${ }^{20}$ R. SobAŃski, Metodologia prawa kanonicznego, Warszawa, UKSW, 2009, s. 34.

${ }^{21}$ S. KAmiński, Metoda $w$ teologii, w: W. Granat, Dogmatyka katolicka, Lublin, Towarzystwo Naukowe KUL 1965, tom wstępny, s. 153.

${ }^{22}$ S. C. NAPIóRKowsKi, Jak uprawiać teologię, s. 83-84.
} 
Czy kanonista pokusi się o taką znajomość metody, skoro punktem wyjścia jego działalności badawczej są dane opracowane przez teologów? Czy może zatem określić swoją metodę jako teologiczną, skoro praktycznie z niej nie korzysta? Sama teologia w badaniach szczegółowych najczęściej korzysta z wybranych elementów metody teologicznej (metody cząstkowe) w zależności od źródeł, celu i przedmiotu badań wpływających na wybór odpowiednich narzędzi badawczych $^{23}$. I w tym kierunku sposobu wykorzystania elementów metody teologicznej idą dywagacje kanonistów.

Określenie właściwej metody badawczej wykorzystywanej w kanonistyce jest konsekwencją określenia przedmiotu poddawanego badaniu. Uznanie właściwych metod, które zmierzają do wyjaśnienia, zrozumienia, przewidywania prawa kanonicznego uzależnione są od rozstrzygnięcia tego, czym to prawo jest (kwestia ontologiczna) i w jaki sposób jest poznawane (kwestia epistemologiczna). W dzisiejszym stanie wiedzy o prawie kanonicznym, po tezach radykalnego już antyjurydyzmu, twierdzenia, w których ujmowane jest ono jako pewna nadbudowa czy element zewnętrzny w stosunku do Kościoła są znamienną rzadkością. Prawo kanoniczne dostrzegane jest jako normatywny wymiar Słowa i sakramentu i istnieje we wspólnocie jako komunii bosko-ludzkiej. Jest prawem w znaczeniu takim, jakie nadaje mu wspólnota, w której ono istnieje. W niej samej należy poszukiwać jego rozumienia. Nie poddaje się ono koncepcyjnym wpływom z zewnątrz, aczkolwiek podkreśla związki ideowe i formalne z prawem społeczności świeckiej.

Prawo kanoniczne, którego natura wypływa ze struktury Kościoła, nie może stanowić przedmiotu poznania jedynie w oparciu o argumentacje nauk prawnych, filozoficznych czy teoretycznych (poziom jurydyczny prawa kanonicznego według Söhngena). Wymaga przejścia na poziom metajurydyczny i metakanoniczny. Na nim spotykamy specyficzny przedmiot materialny poznania prawa kanonicznego, jakim jest Kościół wiary ujmowany w ten sam sposób w kanonistyce jak i teologii. Źródłem wiedzy obydwu nauk są dane Objawienia.

${ }^{23}$ Tamże, s. 93. 
W ramach prawoznawstwa kwestia metod badawczych dotyczy nie tylko pytań o prawo (co to jest prawo), ale również zjawisk prawnych, „to jest stanów rzeczy i zdarzeń związanych z istnieniem i działaniem prawa”, dla których rozstrzygnięcie kwestii ontologicznych i epistemologicznych nie ma decydującego znaczenia. Wybór określonych metod uzależniony jest bowiem od badawczego celu i przedmiotu formalnego (aspekt badawczy) ${ }^{24}$. W kanonistyce jednak zagadnienie zjawisk prawnych prezentuje się pod względem metodologicznym inaczej niż w naukach prawnych. W niej bowiem nie można abstrahować od kwestii ontologicznych, sprowadzając prawo kanoniczne do jedynie praktycznych rozstrzygnięć normatywnych bez dostrzegania go jako elementu struktury zbawczej Kościoła. Jego obecność w strukturze Kościoła ma na celu salus animarum, który wpływa na rozstrzygnięcia normatywne i je warunkuje.

Kanonistyka ma do czynienia z wiedzą z zakresu teologii i korzysta z wiedzy z zakresu nauk prawnych. Trudno jednak, w oparciu o to co wyżej przedstawiłem, twierdzić, że posługuje się metodą prawną czy teologiczną, chyba że pozostaje się na gruncie monizmu metodologicznego w ramach określonej nauki. Z pewnością jednak kanonistyka korzysta z cząstkowych metod teologicznych i tych wypracowanych w naukach prawnych. Rodzi się pytanie o ich zależność w ramach jednej metody określanej jako kanonistyczna, czyli własna metoda kanonistyki. Odpowiedzi nie można uzależniać od faktycznej przewagi jednej z metod nad drugą. Przykładem jest dogmatyka prawa kanonicznego, w której metody prawne przeważają nad teologicznymi. Z sytuacją odwrotną spotykamy się na gruncie teorii (teologii) prawa kanonicznego. Przewaga i doniosłość jednej z metod nie może być rozpatrywana poprzez ich użyteczność w kategoriach ilościowych. Dogmatyka prawa kanonicznego nie może bowiem bazować jedynie na metodologicznych osiągnięciach nauk prawnych. Groziłoby to ujęciem prawnych form życia kościelnego na wzór życia społeczności świeckiej. Nie może również zapoznawać specyfiki

\footnotetext{
${ }^{24}$ J. Guść, Metody badania prawa, w: Leksykon współczesnej teorii i filozofii prawa. 100 podstawowych pojęć, red. J. Zajadło, Warszawa, C. H. Beck, 2007, s. 189.
} 
swoich instytucji, mających teologiczne fundamenty jak i norm, które muszą być formułowane $\mathrm{w}$ sposób pewny i zawsze w zgodzie $\mathrm{z}$ wiarą, misją i prawem Kościoła. Dotyczy to również norm o charakterze, zdawać by się mogło, technicznym jak normy prawa majątkowego czy procesowego Kościoła. Cechą charakterystyczną metod stosowanych w kanonistyce jest ich zależność w znaczeniu wzajemnego oddziaływania. Przedmiot badawczy w obrębie kanonistyki nie może ulegać podziałowi na części, które będą poznawane niezależnie od siebie czy to w ramach jednej czy drugiej metody. Prawo kanoniczne jest bowiem przedmiotem jednoczesnego poznania teologicznego i prawnego, które wzajemnie na siebie wpływają i modyfikują. Przedmiot ujmowany w wierze (Kościół wiary) staje się przedmiotem poznania za pomocą metod prawnych, ze względu na swoją naturę prawną (Kościół w aspekcie prawnym). Dzięki temu kanonistyka wyodrębniła się jako dyscyplina autonomiczna w ramach nauk teologicznych. Ze swej autonomii nie zrezygnowała również w obliczu nauk prawnych, wykorzystując z nich jedynie to, co jest możliwe, dopuszczone i mieści się w rygorach zakreślonych poznaniem teologicznym ${ }^{25}$. Metoda kanonistyczna jest przykładem poznania kompleksowego, w którym analizy naukowe, filozoficzne i teologiczne są na siebie otwarte poszukując w innych dopełnienia w dążeniu do głębszego poznania.

\section{Wnioski}

1. Dyskusja wokół statusu ontologicznego i epistemologicznego prawa kanonicznego zdominowała kanonistykę w drugiej połowie ubiegłego stulecia. Pierwszy problem nie powoduje zbytnich rozbieżności, pomimo iż podejście morfologiczne nie wyparło do końca podejścia addytywnego czy konsekutywnego do prawa kanonicznego. Prawo kościelne jest prawem Kościoła w znaczeniu, iż jego naturę można poznać jedynie w świetle struktury Kościoła, której jest jednym z elementów.

2. Jednoznaczne stanowisko co do statusu ontologicznego prawa kanonicznego nie skutkuje jednak zgodą co do charakteru

${ }^{25}$ W. Aymans, Osservazioni critiche sul metodo della canonistica, s. 118-119. 
naukowego kanonistyki (nauka teologiczna czy prawna) czy epistemologicznego (metoda teologiczna czy prawna) ze wszystkimi możliwymi konsekwencjami ich wzajemnych zestawień. W takich rozwiązaniach zgodność metodologiczna nie wyjaśnia podejścia epistemologicznego (nauka prawna z metodą prawną, nauka teologiczna z metodą teologiczną) jak i podejście epistemologiczne nie uzasadnia związku metodologicznego (nauka teologiczna $\mathrm{z}$ metodą prawną, nauka teologiczna $\mathrm{z}$ metodą teologiczną i prawną).

3. Prace naukowe pisane $z$ kanonistyki nie koncentrują się wokół problematyki ontologicznej prawa kanonicznego. Dotyczą zazwyczaj zjawisk prawnych poddanych badaniu, czyli pewnych stanów związanych $\mathrm{z}$ istnieniem i działaniem prawa. W tych okolicznościach cel badawczy i właściwość przedmiotu (aspekt) wyznaczają metodę badawczą. Posługiwanie się terminem aspektu prawnego w procesie poznawczym Kościoła może okazać się zwodzące. Aspekt to punkt widzenia (prawny aspekt Kościoła jako jeden $\mathrm{z}$ wielu możliwych punktów odniesienia), zewnętrzny w stosunku do przedmiotu badawczego. Kościół natomiast istnieje w aspekcie prawnym. Jako taki nie jest przedmiotem formalnym kanonistyki. W przypadku określenia metody naukowej należy zatem kierować się przede wszystkim celem, który wyznacza drogę oraz doborem odpowiednich narzędzi (odpowiedniość celu i środków), a następnie punktem odniesienia.

4. Wielość zjawisk prawnych będących przedmiotem naukowego postępowania skutkuje wykorzystaniem wielu istniejących metod, które powinny być określone w punkcie wyjścia w zależności od celu i aspektu podejmowanych badań. Mogą być stosowane wyżej wymienione podstawowe metody prawne, ale poprzedzone dokładnym określeniem ich różnych (cząstkowych) postaci i form, znajomością procedur postępowania wraz uzasadnieniem dokonanego wyboru (metody logiczne: dedukcja, indukcja; opisowe: opis, klasyfikacja, typologia, obliczenia statystyczne, itd.). Dotyczy to również metod teologicznych, 
które w pracach z zakresu kanonistyki raczej nie są formułowane, a tym samym nieobecne. Przyczyna takiego stanu rzeczy zdaje się mieć potrójne źródło: (1) koncentracja na tekstach normatywnych i wykorzystywanie metod nauk prawnych z zapoznaniem ich odniesienia do rzeczywistości Kościoła; (2) faktyczny brak opanowania metod teologicznych i prawnych; (3) braki w dostrzeganiu właściwych form zależności pomiędzy metodami. Niewystarczająca znajomość metod nie dotyczy jedynie sposobu ich określenia i nazwania. Nie chodzi o ich stronę nominalną, chociaż i tu pojawiają się archaiczne i odrzucane obecnie ich sformułowania (np. metoda dogmatyczno-prawna zamiast logiczno-językowej), lecz o braki odnoszące się do znajomości poszczególnych etapów (procedur) charakterystycznych dla obranej metody. Tekst prawny nie jest jednak dogmatem. Wymaga zatem innego traktowania.

5. Istniejące metody nie mogą też ograniczać podejmowanych działań przyczyniając się tym samym do hamowania nauki „poprzez niedopuszczanie nowych idei, które są niezgodne z epistemicznymi założeniami tej metody"26. W procesie badawczym powstają nowe metody gdy zjawisko badawcze (prawo) wykracza poza dotychczasowe paradygmaty.

6. Przy trudnościach z określeniem samej metody i procedury postępowania może zatem lepiej jej nie określać, nie sięgać po gotowe nazwy, lecz opisać przyjęty przez siebie sposób postępowania, ale i umieć go uzasadnić i obronić. Droga metodyczna dotyczy stosowania odpowiednio następujących po sobie elementów wzajemnie powiązanych, a nie jej określania.

\section{Usefulness of determining a method in the science of Canon Law}

The article poses the question concerning the usefulness of determining a method used in research on Canon Law, whose perspective is not unambiguous. The author points out that in the discussion about the method

${ }^{26}$ W. ZARĘBA, Problem metody naukowej w kontekście odkrycia, s. 230. 
one does not always distinguish ontological issues (what the Canon Law is) and epistemological ones (how to study it) from the problem of legal phenomenon, that is truths and occurrences connected with the existence and effects of law. It allows to select a study method of legal phenomenon which depends on the research purpose and the properties of the object (aspect), which in canon law must take into consideration its theological perspective.

SŁOWA KLUCZOWE: natura nauki; przedmiot; cel; metoda; prawo kanoniczne; zjawisko prawne

KEY WORDS: nature of science; subject; purpose; method; Canon Law; legal phenomenon

Nota o Autorze:

O. DR hAB. Tomasz GakKowski CP, PROF. UKSW - profesor nadzwyczajny na Wydziale Prawa Kanonicznego UKSW w Warszawie, kierownik zakładu Teorii Prawa Kanonicznego w katedrze Teorii i Norm Ogólnych Prawa Kanonicznego. 